\title{
Virtual Reality Simulation as a Tool to Monitor Surgical Performance Indicators: VIRESI Observational Study
}

\author{
Simulação em Realidade Virtual como Ferramenta na \\ Monitorização de Indicadores do Desempenho Cirúrgico: \\ Estudo Observacional VIRESI
}

Nuno MURALHA ${ }^{1}$, Manuel OLIVEIRA ${ }^{1}$, Maria Amélia FERREIRA ${ }^{2}$, José COSTA-MAIA ${ }^{1}$

Acta Med Port 2017 May;30(5):388-394 - https://doi.org/10.20344/amp.7983

\section{ABSTRACT}

Introduction: Virtual reality simulation is a topic of discussion as a complementary tool to traditional laparoscopic surgical training in the operating room. However, it is unclear whether virtual reality training can have an impact on the surgical performance of advanced laparoscopic procedures. Our objective was to assess the ability of the virtual reality simulator LAP Mentor to identify and quantify changes in surgical performance indicators, after LAP Mentor training for digestive anastomosis.

Material and Methods: Twelve surgeons from Centro Hospitalar de São João in Porto (Portugal) performed two sessions of advanced task 5: anastomosis in LAP Mentor, before and after completing the tutorial, and were evaluated on 34 surgical performance indicators. Results: The results show that six surgical performance indicators significantly changed after LAP Mentor training. The surgeons performed the task significantly faster as the median 'total time' significantly reduced $(p<0.05)$ from 759.5 to 523.5 seconds. Significant decreases $(p<0.05)$ were also found in median 'total needle loading time' (303.3 to 107.8 seconds), 'average needle loading time' (38.5 to 31.0 seconds), 'number of passages in which the needle passed precisely through the entrance dots' (2.5 to 1.0$)$, 'time the needle was held outside the visible field' (20.9 to 2.4 seconds), and 'total time the needle-holders' ends are kept outside the predefined operative field' (88.2 to 49.6 seconds).

Discussion: This study raises the possibility of using virtual reality training simulation as a benchmark tool to assess the surgical performance of Portuguese surgeons.

Conclusion: LAP Mentor is able to identify variations in surgical performance indicators of digestive anastomosis.

Keywords: Anastomosis, Surgical; Laparoscopy/education; Portugal; Simulation Training

\section{RESUMO}

Introdução: A simulação de procedimentos cirúrgicos através de realidade virtual é referida como uma alternativa complementar ao treino tradicional de laparoscopia no bloco operatório. Pretendeu-se avaliar a capacidade do simulador de realidade virtual LAP Mentor para identificar variações em indicadores de desempenho cirúrgico, após a sessão de treino em anastomose digestiva.

Material e Métodos: Um grupo de 12 cirurgiões do Centro Hospitalar de São João do Porto realizou duas sessões da tarefa de anastomose do LAP Mentor, antes e depois da formação fornecida pelo simulador. Foram avaliados 34 indicadores de desempenho cirúrgico em cada sessão.

Resultados: Seis indicadores de desempenho cirúrgico apresentaram variações significativas após o treino realizado. A mediana do 'tempo total' necessário para completar a tarefa diminuiu significativamente $(p<0,05)$ de 759,5 para 523,5 segundos. Verificámos uma diminuição significativa $(p<0,05)$ nas medianas dos indicadores 'tempo total de carregar a agulha no porta-agulhas' (303,3 para 107,8 segundos), 'tempo médio de carregamento da agulha' (38,5 para 31,0 segundos), 'número de passagens em que a agulha passou precisamente através dos pontos de entrada' (2,5 para 1,0), 'tempo em que a agulha foi manipulada fora do campo de visão' (20,9 para 2,4 segundos), e 'tempo total em que as extremidades dos porta-agulhas foram mantidas fora do campo operatório' (88,2 para 49,6 segundos).

Discussão: Este estudo mostra o potencial da realidade virtual servir como ferramenta para a avaliação do desempenho cirúrgico dos cirurgiões portugueses.

Conclusão: O simulador de realidade virtual LAP Mentor tem a capacidade de identificar variações em indicadores de desempenho cirúrgico de anastomose digestiva.

Palavras-chave: Anastomose Cirúrgica; Laparoscopia/educação; Portugal; Treino de Simulação

\section{INTRODUCTION}

Traditionally, junior surgeons develop their technical skills through a process of increasing involvement in the surgical procedures carried out in the operating room (OR), under the supervision of a senior surgeon. ${ }^{1}$ This approach, however, has been associated with longer operating times, increased costs, ${ }^{2}$ and higher rates of surgical complications. ${ }^{3,4}$ Furthermore, laparoscopy requires specific psychomotor abilities that differ substantially from those of conventional surgery (e.g. altered tactile feedback, different eye-to-hand coordination, translation of two dimensional to three dimensional image, and fulcrum effect), ${ }^{5,6}$ that are difficult to acquire in the OR. ${ }^{7}$ Therefore, alternative methods have been developed for training laparoscopy outside of the OR such as box trainers, animal models, and virtual reality (VR) simulation. ${ }^{1}$

VR simulation has been used to train and assess

1. General Surgery Department. Centro Hospitalar de São João. Porto. Portugal.

2. Department of Medical Education and Simulation. Faculdade de Medicina. Universidade do Porto. Porto. Portugal.

$\bowtie$ Autor correspondente: Nuno Muralha. nunomuralha@gmail.com

Recebido: 24 de junho de 2016 - Aceite: 06 de fevereiro de 2017 | Copyright $\odot$ Ordem dos Médicos 2017 
surgical skills (using objective performance indicators) in a relaxed environment outside the OR, without exposing patients to unnecessary risks and without the need of supervision. ${ }^{8}$ However, studies suggest that VR simulation alone is not as effective as traditional training for certain procedures (e.g. sigmoidoscopy), ${ }^{9}$ because current simulation is not able to mimic the anatomical variations that are common throughout the different body systems. ${ }^{10}$ Therefore, VR simulation has been used primarily for developing technical surgical skills, rather than for decision-making skills. ${ }^{9}$ Furthermore, although VR simulation seems to decrease operative time and improve surgical performance of junior surgeons, it remains unclear whether this may have a positive impact in patient outcomes. ${ }^{11}$

LAP Mentor is a laparoscopic VR simulator, whose construct validity (i.e. ability to distinguish the performance of surgeons with different performance levels) has been demonstrated for several basic exercises in non-anatomical models (aimed at improving, for example, orientation, eye-to-hand coordination, and manual movement), ${ }^{12-14}$ and for exercises in anatomical models for procedures such as cholecystectomy, ${ }^{15}$ sigmoid colectomy, ${ }^{16}$ gastric bypass, ${ }^{17}$ salpingectomy, ${ }^{18}$ and bariatric surgery (jejunojejunostomy). ${ }^{19}$ Furthermore, training with LAP Mentor has been associated with improved surgical performance both in porcine models (e.g. laparoscopic nephrectomy, ${ }^{20}$ and basic laparoscopic techniques ${ }^{21}$ ) and in real patients (e.g. camera navigation). ${ }^{22}$ Finally, training with LAP Mentor plus traditional mentorship showed a significantly higher improvement in skills for laparoscopic cholecystectomy in real patients, when compared to traditional mentorship alone. ${ }^{23}$ Despite this, further research is required for investigating the impact of LAP Mentor training tutorials in surgical performance, such as that for digestive anastomosis.

The objective of our study was to investigate whether LAP Mentor is able to identify changes in surgical performance indicators, after LAP Mentor training for digestive anastomosis. Here we report the first study about virtual reality surgical simulation training in Portugal.

\section{MATERIAL AND METHODS}

\section{Study design}

This study was conducted at Centro Hospitalar de São João in Porto (Portugal). Surgeons were asked to undertake the 'advanced task 5: anastomosis' in LAP Mentor, before (repetition 1) and after (repetition 2) carrying out the training tutorial for the task available in this VR simulator. Surgical performance indicators were assessed both for repetitions 1 and 2. Surgeons could take up to 20 minutes to complete the task in each of the repetitions.

All surgeons had a 5-minute period to familiarize themselves with the simulator, before performing the repetition 1 .

\section{Participants}

All participants were surgeons from Centro Hospitalar de São João in Porto (Portugal) who volunteered to participate in our study, and all of them were recruited between the $1^{\text {st }}$ and the $21^{\text {st }}$ of July 2015 . Only participants with no previous experience with LAP Mentor, or with any other laparoscopic VR simulators, were recruited.

\section{Virtual reality simulator}

We used the laparoscopic VR simulator LAP Mentor ${ }^{\mathrm{TM}}$ II (Simbionix ${ }^{\circledR}$, Cleveland, Ohio) in our study. This simulator includes a camera and two instrumental channels, connected to a computer and a foot pedal. The laparoscopic training procedure is performed using two hybrid instruments, which have real handles and virtual ends simulating graspers, scissors, staplers, and energy devices (Fig. 1). This version of LAP Mentor provides haptic feedback. LAP Mentor possesses a software that is able to simulate not only nonanatomical settings for training basic surgical skills (e.g. camera manipulation and translocating objects), but also the peritoneal cavity for training more advanced surgical skills (e.g. advanced suturing and gastric bypass).

All participants performed a manual anastomosis (i.e. advanced task 5: anastomosis from the advanced suturing module). In this task, the surgeon is required to anastomose two segments of 'small bowel' placed aside (Fig. 2). The opening on the 'bowel' is clearly visible and, using the instruments previously described, the surgeon performs a running suture to close the bowel wall defect. No participants received intraoperative assistance while performing the simulated surgery.

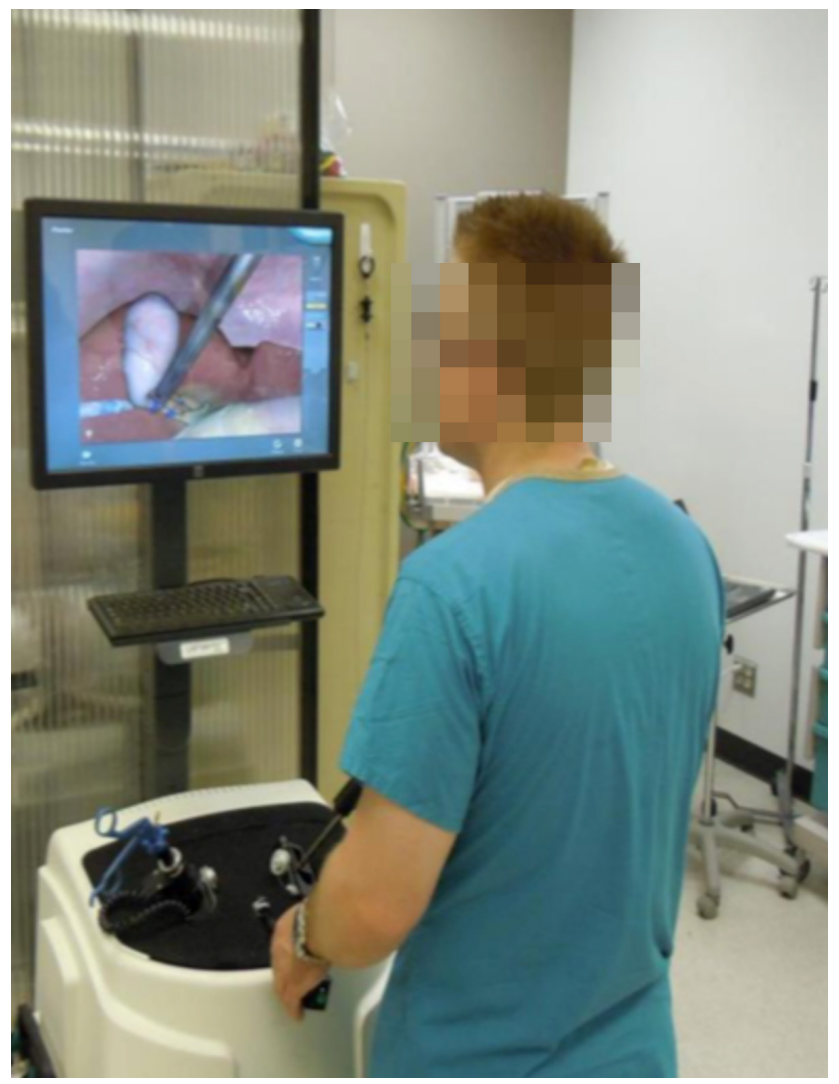

Figure 1 - Practicing laparoscopic cholecystectomy on LAP Mentor 


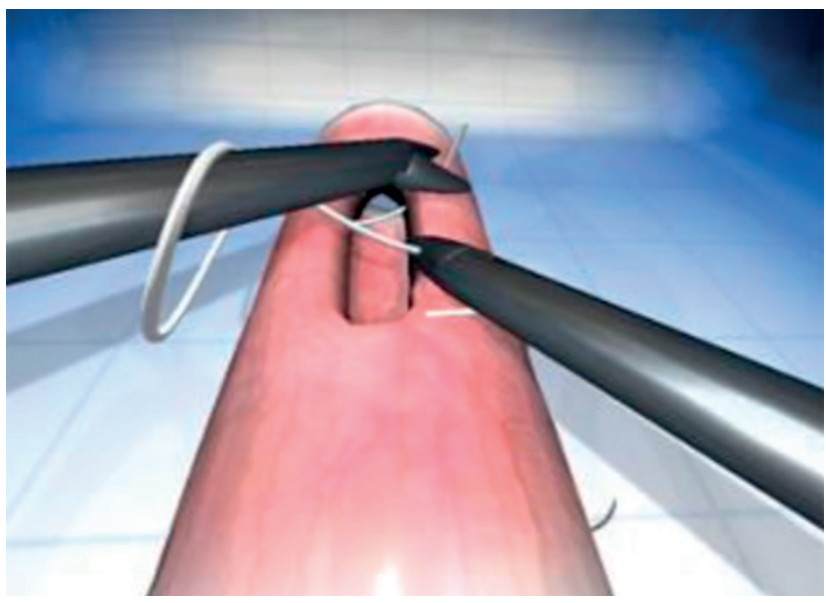

Figure 2 - Representation of the simulated procedure (advanced task 5: anastomosis)

\section{Surgical performance indicators}

We used all of the 34 quantitative specific metrics provided by LAP Mentor to assess manual anastomosis surgical performance.

\section{Statistical analysis}

Demographic and surgical experience data were presented as mean ( \pm standard deviation) or as absolute number (percentage). The results for each surgical performance indicator were presented as median (quartile 1 ; quartile 3 ), and the results obtained for repetitions 1 and 2 were compared using a Wilcoxon signed rank test. Statistical significance was defined by a $p$ - value $<0.05$. All of the data were analyzed using software $R$, version 3.2.2 for Mac OS X.

\section{RESULTS}

\section{Demographic and surgical experience}

Twelve participants were included in our study and their demographic and surgical experience data are presented in Table 1. Briefly, their mean age was 47.4 years, $91.6 \%$ were right handed and their surgical specialties were hepatobiliary $(25.0 \%)$, colorectal $(16.7 \%)$, bariatric $(33.3 \%)$, and general $(25.0 \%)$.

\section{Surgical performance indicators}

The median values obtained for the surgical performance indicators are presented in Table 2.

Statistically significant changes were identified between repetitions 1 and 2 in six out of the 34 investigated performance indicators (Fig. 3). The surgeons took significantly less time to finish the task, as the 'total time' was significantly reduced $(p<0.05)$ from $759.5(641.3 ; 991.5)$ to $523.5(435.0 ; 739.5)$ seconds, from repetition 1 to 2 . In addition, there also was a significant reduction $(p<0.05)$ in the time needed for loading the needles in the needle holder, as the 'total needle loading time' was reduced from $303.3(206.2 ; 360.3)$ to $107.8(97.7 ; 205.7)$ seconds, and the 'average needle loading time' from $38.5(28.6 ; 57.1)$ to 31.0 $(22.0 ; 42.2)$ seconds. The 'number of passages in which the needle passed precisely through the entrance dots' was also significantly reduced $(p<0.05)$ from $2.5(2.0 ; 3.0)$ to $1.0(1.0 ; 2.3)$, between repetition 1 and 2 . Finally, the 'time the needle was held outside the visible field' significantly decreased $(p<0.05)$ from $20.9(2.7 ; 36.9)$ to $2.4(0.2 ; 16.2)$ seconds, and 'total time the needle-holders' ends are kept outside the predefined operative field' also decreased from $88.2(74.6 ; 142.1)$ to $49.6(41.4 ; 114.6)$ seconds, between repetitions 1 and 2 .

\section{DISCUSSION}

In this study, we investigated whether LAP Mentor is able to identify changes in surgical performance indicators after LAP Mentor training for 'advanced task 5: anastomosis'. Our study suggests that LAP Mentor is able to identify the aforementioned variations, as we found that six out of the 34 surgical performance indicators significantly changed after the training with this VR simulator. This was the first study about VR surgical simulation of laparoscopy in the Portuguese setting.

Our study suggests that training with LAP Mentor reduces the time to complete 'advanced task 5: anastomosis', mainly due to the reduction of the time consumption for loading the needle. Indeed, we found that after LAP Mentor training, there was a significant improvement in the performance indicators regarding the time to complete the full procedure (i.e. 'total time') and in those regarding the time to load the needle (i.e. 'total needle loading time' and 'average needle loading time'). We were not able to find, however, any significant changes in performance indicators for other tasks that might have impact on the time to complete the full procedure such as suturing (i.e. 'total time to accomplish the suture') and forming the knot (i.e. 'total time to form a knot'). To reduce needle loading time is clinically relevant, as this is a basic and skill-demanding technique used in all laparoscopic procedures.

Interestingly, we also found that the 'number of passages in which the needle passed precisely through the entrance dots' decreased after the training, suggesting that the stitching accuracy decreased between repetitions 1 and 2 . One possible justification for this may be that the surgeons were more fatigued in repetition 2 than in repetition 1 . Despite this, we did not identify any significant changes

\begin{tabular}{|c|c|}
\hline Characteristics $(n=12)$ & \\
\hline Age in years, mean (SD) & $47.4(9.7)$ \\
\hline Male, No. (\%) & $10(83.3)$ \\
\hline Right handed, No. (\%) & $11(91.6)$ \\
\hline Experience in years, mean (SD) & $14.0(8.9)$ \\
\hline \multicolumn{2}{|l|}{ Surgical specialty, No. (\%) } \\
\hline Hepatobiliary & $3(25.0)$ \\
\hline Colorectal & $2(16.7)$ \\
\hline Bariatric & $4(33.3)$ \\
\hline General & $3(25.0)$ \\
\hline
\end{tabular}


Table 2 - Results for surgical performance indicators

\begin{tabular}{|c|c|c|c|}
\hline Performance indicator & $\begin{array}{l}\text { Repetition 1, median } \\
\text { (Q1; Q3) }\end{array}$ & $\begin{array}{l}\text { Repetition 2, median } \\
\text { (Q1; Q3) }\end{array}$ & $p$ - value ${ }^{\S}$ \\
\hline Total time, seconds & $759.5(641.3 ; 991.5)$ & $523.5(435.0 ; 739.5)$ & $0.028^{*}$ \\
\hline Total number of needle loadings & $1.0(1.0 ; 1.0)$ & $1.0(1.0 ; 1.0)$ & NA \\
\hline Total needle loading time, seconds & $303.3(206.2 ; 360.3)$ & $107.8(97.7 ; 205.7)$ & $0.003^{*}$ \\
\hline Average needle loading time, seconds & $38.5(28.6 ; 57.1)$ & $31.0(22.0 ; 42.2)$ & $0.034^{*}$ \\
\hline Total number of needle passages & $6.0(5.0 ; 7.3)$ & $5.5(3.0 ; 6.0)$ & 0.072 \\
\hline $\begin{array}{l}\text { Number of needle passages in which the needle was held at } \\
\text { approximately } 90 \text { Angstrom degrees }{ }^{\dagger} \text { relative to the suture line }\end{array}$ & $1.0(0.8 ; 2.3)$ & $1.5(0.8 ; 3.0)$ & 0.764 \\
\hline $\begin{array}{l}\text { Percentage of needle passages in which the needle is held at } \\
\text { approximately } 90 \text { Angstrom degrees }{ }^{\dagger} \text { relative to the suture line }\end{array}$ & $21.1(12.5 ; 28.1)$ & $35.4(12.5 ; 50.0)$ & 0.292 \\
\hline $\begin{array}{l}\text { Number of passages the needle was inserted into the tissue at an } \\
\text { approach angle of } 60 \text { Angstrom degrees to } 90 \text { Angstrom degrees } \\
\text { relative to the tissue surface }\end{array}$ & $2.5(1.0 ; 3.3)$ & $2.0(1.0 ; 2.0)$ & 0.334 \\
\hline $\begin{array}{l}\text { Percentage of needle passages at an approach angle of } 60 \text { Angstrom } \\
\text { degrees to } 90 \text { Angstrom degrees relative to the tissue surface }\end{array}$ & $31.3(21.7 ; 54.2)$ & $33.3(16.7 ; 52.5)$ & 0.735 \\
\hline $\begin{array}{l}\text { Total number of entrances and exit points through which the needle } \\
\text { has passed }\end{array}$ & $17.0(12.8 ; 21.0)$ & $12.0(12.0 ; 14.0)$ & 0.294 \\
\hline $\begin{array}{l}\text { Number of passages in which the needle passed precisely through } \\
\text { the entrance dots }\end{array}$ & $2.5(2.0 ; 3.0)$ & $1.0(1.0 ; 2.3)$ & $0.008^{*}$ \\
\hline $\begin{array}{l}\text { Number of passages in which the needle passed precisely through } \\
\text { the exit dots }\end{array}$ & $2.0(1.0 ; 3.0)$ & $1.5(0.8 ; 2.3)$ & 0.472 \\
\hline $\begin{array}{l}\text { Accuracy rate at precise needle passage through the entrance and } \\
\text { exit dots, } \%\end{array}$ & $25.0(18.8 ; 40.0)$ & $22.5(9.6 ; 28.8)$ & 0.090 \\
\hline $\begin{array}{l}\text { Average distance between the marked dots and the points through } \\
\text { which the needle has passed, } \mathrm{mm}\end{array}$ & $6.5(6.3 ; 6.8)$ & $6.2(5.9 ; 7.6)$ & 0.793 \\
\hline Number of unnecessary needle piercing points & $1.0(1.0 ; 1.0)$ & $1.0(1.0 ; 1.0)$ & NA \\
\hline Strain during needle passage & $1.0(1.0 ; 1.0)$ & $1.0(1.0 ; 1.0)$ & NA \\
\hline Total amount of strain applied to tissue during needle passages & $21.8(18.3 ; 30.5)$ & $23.0(10.0 ; 33.1)$ & 0.618 \\
\hline Average amount of strain applied to tissue during needle passages & $4.3(2.5 ; 4.7)$ & $4.5(2.0 ; 6.3)$ & 0.147 \\
\hline Stitch - Thread shear force on the exit point & $1.0(1.0 ; 1.0)$ & $1.0(1.0 ; 1.0)$ & NA \\
\hline Total time to form a knot, seconds & $104.1(84.7 ; 191.9)$ & $107.6(54.7 ; 161.3)$ & 0.153 \\
\hline Knot type & $-1.0(-1.0 ;-1.0)$ & $-1.0(-1.0 ;-1.0)$ & NA \\
\hline Total number of completed knots & $1.0(1.0 ; 1.0)$ & $1.0(1.0 ; 1.0)$ & NA \\
\hline Knot tail length ${ }^{\ddagger}, \mathrm{mm}$ & $9.0(3.9 ; 12.7)$ & $15.6(11.9 ; 25.7)$ & 0.205 \\
\hline Number of half knots performed for each completed knot & $3.0(3.0 ; 4.0)$ & $3.0(3.0 ; 3.0)$ & 0.215 \\
\hline Total time to accomplish the suture, seconds & $517.1(457.1 ; 791.5)$ & $427.4(297.4 ; 518.4)$ & 0.078 \\
\hline Total number of stitches & $4.0(3.0 ; 5.3)$ & $3.0(3.0 ; 3.5)$ & 0.237 \\
\hline Time the needle was held outside the visible field, seconds & $20.9(2.7 ; 36.9)$ & $2.4(0.2 ; 16.2)$ & $0.039^{*}$ \\
\hline $\begin{array}{l}\text { Number of times the grasped needle was taken outside the visible } \\
\text { field }\end{array}$ & $1.0(1.0 ; 1.0)$ & $1.0(1.0 ; 1.0)$ & NA \\
\hline The percentage of time the needle was held outside the visible field & $3.2(0.3 ; 4.5)$ & $0.4(0.0 ; 3.5)$ & 0.059 \\
\hline Total aggressive tissue handling & $5.6(2.7 ; 14.0)$ & $6.7(1.9 ; 47.7)$ & 0.421 \\
\hline $\begin{array}{l}\text { Number of times the needle-holders' ends are kept outside the } \\
\text { predefined operative field }\end{array}$ & $59.0(35.8 ; 75.0)$ & $41.0(26.0 ; 53.5)$ & 0.072 \\
\hline $\begin{array}{l}\text { Total time the needle-holders' ends are kept outside the predefined } \\
\text { operative field, seconds }\end{array}$ & $88.2(74.6 ; 142.1)$ & $49.6(41.4 ; 114.6)$ & $0.026^{*}$ \\
\hline $\begin{array}{l}\text { The percentage of time the needle-holders' ends are kept outside the } \\
\text { operative field }\end{array}$ & $13.2(11.6 ; 14.8)$ & $11.2(7.7 ; 16.5)$ & 0.426 \\
\hline Number of dropped needles & $11.5(5.8 ; 16.5)$ & $10(6.8 ; 11.8)$ & 0.723 \\
\hline
\end{tabular}

Q1: Quartile 1; Q3: Quartile 3; NA: Not applicable; § Wilcoxon test; † 20 Angstrom degrees deviation; $\ddagger$ Deviation from the predefined knot’s tail default length; * $p<0.05$. 
A

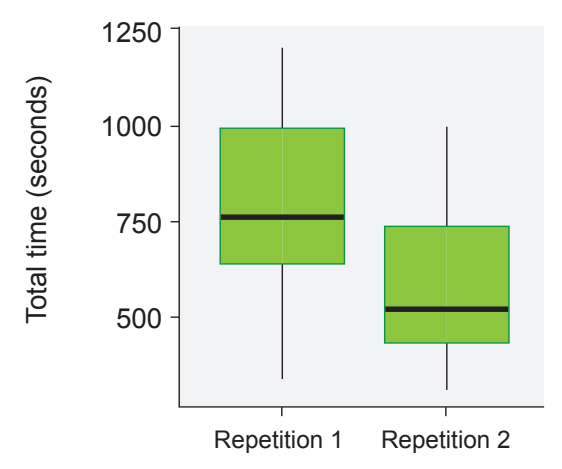

D

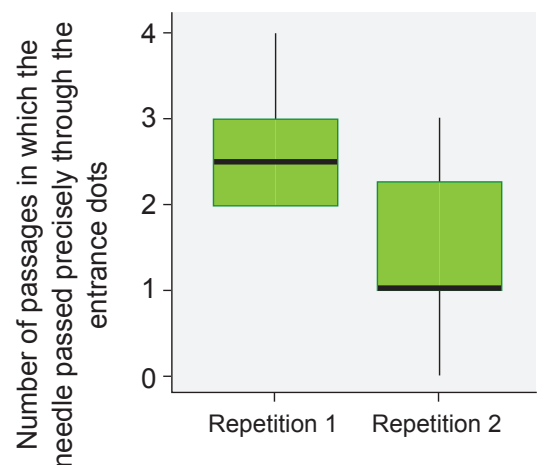

B
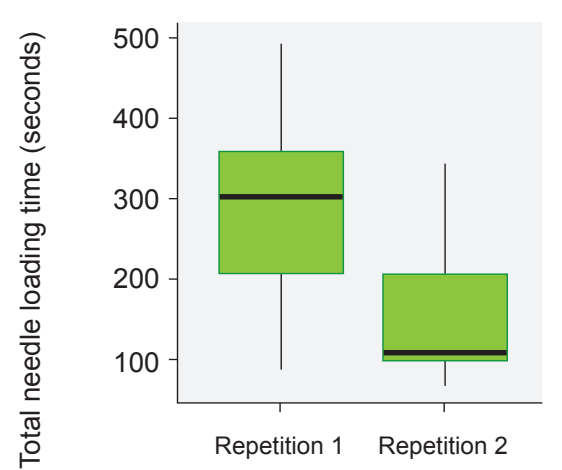

E
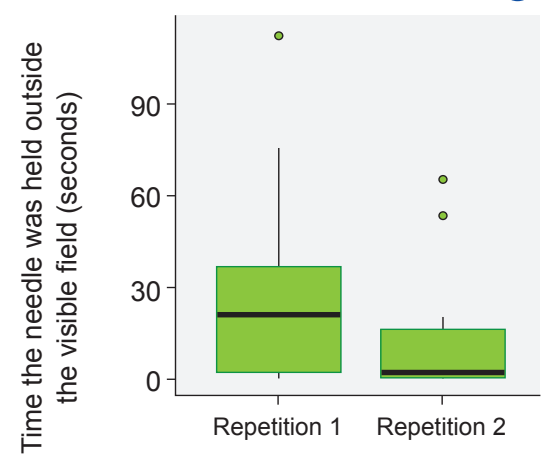
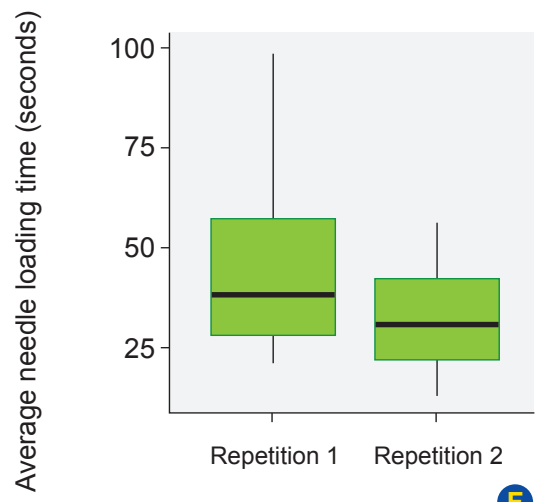

F

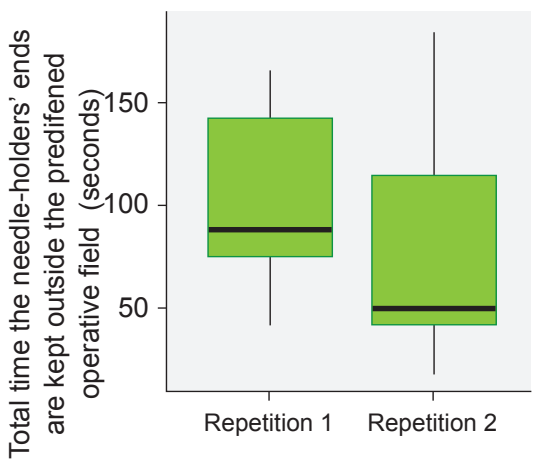

Figure 3 - Comparison of the results for repetition 1 and repetition 2 of surgical performance indicators: (A) total time, (B) total needle loading time, (C) average needle loading time, (D) number of passages in which the needle passed precisely through the entrance dots, (E) time the needle was held outside the visible field, and (F) total time the needle-holders' ends are kept outside the predefined operative field.

in other performance indicators related to the accuracy of stitching, such as 'number of passages in which the needle passed precisely through the exit dots', 'accuracy rate at precise needle passage through the entrance and exit dots', and 'number of unnecessary needle piercing points'.

Our study also suggests that training with LAP Mentor improves the safety of procedure 'advanced task 5: anastomosis'. In fact, there was a significant improvement in the performance indicators 'time the needle was held outside the visible field' and 'total time the needle-holders' ends are kept outside the predefined operative field'. These results are clinically relevant, as they may suggest that during repetition 2 the surgeon kept the needle inside their visible field, minimizing the potential for accidentally damaging tissues/organs outside of the visible field.

Several limitations may be presented for this study: firstly, we recruited a small sample of experienced surgeons from a single hospital, and therefore our findings may not apply to other samples of surgeons (e.g. inexperienced surgeons), and for surgeons recruited from other hospitals. Secondly, we did not take into account potential confounders that may have had impact in the surgical performance indicators that were investigated. Examples of such confounders may be sleep deprivation and fatigue (as these have been shown to have impact in cognitive and psychomotor skills ${ }^{24}$ ) and previous experience with video games (as this has been shown to improve bimanual dexterity and expedite the acquisition of basic surgical skills). ${ }^{25}$ Finally, we did not include a control group in our study (carrying out two repetitions of 'advanced task 5: anastomosis' in LAP Mentor without undertaking the training tutorial for this task). Therefore, we cannot be sure that there is a causal relationship between the training tutorial and the changes that we identified in the surgical performance indicators. Indeed, these may have been a consequence of adaptation to the VR trainer, rather than a result of surgical skill improvement after the tutorial. We tried to minimize this potential adaptation, by allowing all surgeons to familiarize themselves with LAP Mentor during a 5-minute period, before performing the repetition 1.

Despite the above limitations, our results are supported by the literature. Previous studies have also reported that LAP Mentor can be used to assess surgical performance after laparoscopy training courses:26-28 in a recent study ${ }^{26}$ including 12 general surgery residents, LAP Mentor identified a significant improvement in surgical skill indicators (e.g. mean total time for hand-to-hand coordination) after a training course including a theory session (one hour), handson simulation with LAP Mentor (seven hours), and hands-on session with an animal model (13 hours). Furthermore, in a study ${ }^{28}$ that randomized 20 students into training group (i.e. structured laparoscopic tasks in fresh frozen cadaver) or control (i.e. no training), LAP Mentor was also able to identify a significant improvement in surgical performance indicators (i.e. safety of cautery and left arm path length, for laparoscopic cholecystectomy) in the training versus control groups. In this study, LAP Mentor was also able to 
identify significant improvements in surgical performance indicators in subsequent repetitions for the tasks of nondominant to dominant hand peg transfer, intracorporeal and extracorporeal knot tying.

In addition, it has been reported that training with LAP Mentor improves surgical performance indicators: ${ }^{18,29} \mathrm{~A}$ study reported that this type of training (for basic tasks in non-anatomical models) leads to a significant improvement in time and accuracy of camera manipulation, time of clip application, and time, speed, total path and total movements in object retrieval. ${ }^{29}$ In another study, ${ }^{18}$ LAP Mentor was used to investigate the learning curve of nine novice gynecologic surgeons, under LAP Mentor training for salpingectomy and salpingotomy. It was reported that the learning curve for salpingectomy reached a plateau after eight training sessions for 'time taken', and after four training sessions for 'number of movements'. Similarly, the learning curve for salpingotomy reached a plateau after eight training sessions both for 'time taken' and 'number of movements'.

Our findings may have important implications for future research, as they potentially allow us to select LAP Mentor as a device to assess surgical performance indicators. This constitutes an important step towards the development of a multicentric study about the characterization of these indicators in the Portuguese surgical community (that we are currently gathering efforts to implement), which will allow the establishment of surgical performance benchmarks for Portuguese surgeons with different levels of experience.

Furthermore, our findings may also raise the awareness of Portuguese decision-makers, for the possibility of developing surgical training programs using VR simulators (e.g. LAP Mentor ${ }^{T M}$, LapSim ${ }^{\circledR}$, MIST-VR, SimSurgery ${ }^{\circledR}$, and SINERGIA). The main advantage of this approach seems to be that it improves surgical skills without the need for animal models, human bodies or real patients. Furthermore, unlike with box trainers, VR simulators allow an objective assessment of surgical performance indicators, which may play an important role in the assessment of the outcome of training programs, accreditation and recertification of surgeons. Conversely, further research is still needed to investigate the effect of VR simulators on the performance of advanced laparoscopic procedures, and patient outcomes. ${ }^{1,11}$ Additionally, the costs of VR

\section{REFERENCES}

1. Yiannakopoulou E, Nikiteas N, Perrea D, Tsigris C. Virtual reality simulators and training in laparoscopic surgery. Int J Surg. 2015;13:604.

2. Bridges $M$, Diamond $D L$. The financial impact of teaching surgical residents in the operating room. Am J Surg. 1999;177:28-32.

3. Kauvar DS, Braswell A, Brown BD, Harnisch M. Influence of resident and attending surgeon seniority on operative performance in laparoscopic cholecystectomy. J Surg Res. 2006;132:159-63.

4. Wilkiemeyer M, Pappas TN, Giobbie-Hurder A, Itani KM, Jonasson O, Neumayer LA. Does resident post graduate year influence the outcomes of inguinal hernia repair? Ann Surg. 2005;241:879-82.

5. Crothers IR, Gallagher AG, McClure N, James DT, McGuigan J. Experienced laparoscopic surgeons are automated to the "fulcrum simulation are considerable and need to be weighed with other alternatives, depending on the available budget. For example, according to a study published in 2007, a box trainer with electrocautery and endoscopic clip applier costs around \$30 000 (€26 412) (without taking into account the costs of organ purchase, preparation and expert supervision) and a VR training simulator costs between $\$ 50$ 000 (€44 019) and $\$ 87000$ (€76 593). ${ }^{30}$

\section{CONCLUSION}

In conclusion, our study shows that LAP Mentor is able to identify changes in surgical performance indicators. Indeed, after undertaking the 'advanced task 5: anastomosis' in LAP Mentor, this VR simulator was able to identify an improvement in the surgical performance indicators of our sample of surgeons for 'total time', 'total needle loading time', 'average needle loading time', 'time the needle was held outside the visible field', 'total time the needle-holders' ends are kept outside the predefined operative field', and a decline for the 'number of passages in which the needle passed precisely through the entrance dots'.

\section{ACKNOWLEDGEMENTS}

The authors would like to thank to the volunteers from the Department of General Surgery of Centro Hospitalar de São João EPE for the collaboration in this study.

\section{PROTECTION OF HUMANS AND ANIMALS}

The authors declare that the procedures were followed according to the regulations established by the Clinical Research and Ethics Committee and to the Helsinki Declaration of the World Medical Association.

\section{DATA CONFIDENTIALITY}

The authors declare having followed the protocols in use at their working center regarding patients' data publication.

\section{CONFLICT OF INTEREST}

The authors have no conflict of interest to declare.

\section{FUNDING}

Taper - Equipamentos de Precisão Científica Lda. and Scientific Toolbox Consulting contributed with a grant and logistical support to this study. effect": an ergonomic demonstration. Endoscopy. 1999;31:365-9.

6. Gallagher AG, McClure N, McGuigan J, Crothers I, Browning J. Virtual reality training in laparoscopic surgery: a preliminary assessment of minimally invasive surgical trainer virtual reality (MIST VR). Endoscopy. 1999;31:310-3.

7. Scott DJ, Bergen PC, Rege RV, Laycock R, Tesfay ST, Valentine RJ, et al. Laparoscopic training on bench models: better and more cost effective than operating room experience? J Am Coll Surg. 2000;191:272-83.

8. Botden SM, Jakimowicz JJ. What is going on in augmented reality simulation in laparoscopic surgery? Surg Endosc. 2009;23:1693-700.

9. Gerson LB, Van Dam J. A prospective randomized trial comparing a virtual reality simulator to bedside teaching for training in sigmoidoscopy. Endoscopy. 2003;35:569-75. 
10. Izuishi K, Toyama Y, Nakano S, Goda F, Usuki H, Masaki T, et al. Preoperative assessment of the aberrant bile duct using multislice computed tomography cholangiography. Am J Surg. 2005;189:53-5.

11. Nagendran M, Gurusamy KS, Aggarwal R, Loizidou M, Davidson BR. Virtual reality training for surgical trainees in laparoscopic surgery. Cochrane Database Syst Rev. 2013;8:CD006575.

12. Matsuda T, McDougall EM, Ono Y, Hattori R, Baba S, Iwamura M, et al. Positive correlation between motion analysis data on the LapMentor virtual reality laparoscopic surgical simulator and the results from videotape assessment of real laparoscopic surgeries. J Endourol. 2012;26:1506-11.

13. McDougall EM, Corica FA, Boker JR, Sala LG, Stoliar G, Borin JF, et al. Construct validity testing of a laparoscopic surgical simulator. J Am Coll Surg. 2006;202:779-87.

14. Yamaguchi S, Konishi K, Yasunaga T, Yoshida D, Kinjo N, Kobayashi K, et al. Construct validity for eye-hand coordination skill on a virtual reality laparoscopic surgical simulator. Surg Endosc. 2007;21:2253-7.

15. Van Bruwaene S, Schijven MP, Miserez M. Assessment of procedural skills using virtual simulation remains a challenge. J Surg Educ. 2014;71:654-61.

16. Shanmugan S, Leblanc F, Senagore AJ, Ellis CN, Stein SL, Khan S, et al. Virtual reality simulator training for laparoscopic colectomy: what metrics have construct validity? Dis Colon Rectum. 2014;57:210-4.

17. Giannotti D, Patrizi G, Casella G, Di Rocco G, Marchetti M, Frezzotti $\mathrm{F}$, et al. Can virtual reality simulators be a certification tool for bariatric surgeons? Surg Endosc. 2014;28:242-8.

18. Bharathan R, Vali S, Setchell T, Miskry T, Darzi A, Aggarwal R. Psychomotor skills and cognitive load training on a virtual reality laparoscopic simulator for tubal surgery is effective. Eur $\mathrm{J}$ Obstet Gynecol Reprod Biol. 2013;169:347-52.

19. Lewis TM, Aggarwal R, Kwasnicki RM, Rajaretnam N, Moorthy K, Ahmed $A$, et al. Can virtual reality simulation be used for advanced bariatric surgical training? Surgery. 2012;151:779-84.

20. Lucas SM, Zeltser IS, Bensalah K, Tuncel A, Jenkins A, Pearle MS, et al. Training on a virtual reality laparoscopic simulator improves performance of an unfamiliar live laparoscopic procedure. J Urol. 2008;180:2588-91.

21. Andreatta PB, Woodrum DT, Birkmeyer JD, Yellamanchilli RK, Doherty GM, Gauger PG, et al. Laparoscopic skills are improved with LapMentor training: results of a randomized, double-blinded study. Ann Surg. 2006;243:854-60.

22. Franzeck FM, Rosenthal R, Muller MK, Nocito A, Wittich F, Maurus C, et al. Prospective randomized controlled trial of simulator-based versus traditional in-surgery laparoscopic camera navigation training. Surg Endosc. 2012;26:235-41.

23. Beyer L, Troyer JD, Mancini J, Bladou F, Berdah SV, Karsenty G. Impact of laparoscopy simulator training on the technical skills of future surgeons in the operating room: a prospective study. Am J Surg. 2011;202:265-72.

24. Gerdes J, Kahol K, Smith M, Leyba MJ, Ferrara JJ. Jack Barney award: the effect of fatigue on cognitive and psychomotor skills of trauma residents and attending surgeons. Am J Surg. 2008;196:813-9.

25. Middleton KK, Hamilton T, Tsai PC, Middleton DB, Falcone JL, Hamad G. Improved nondominant hand performance on a laparoscopic virtual reality simulator after playing the Nintendo Wii. Surg Endosc. 2013;27:4224-31.

26. Enciso S, Diaz-Guemes I, Uson J, Sanchez-Margallo FM. Validation of a model of intensive training in digestive laparoscopic surgery. Cir Esp. 2016;94:70-6.

27. Sarker SJ, Telfah MM, Onuba L, Patel BP. Objective assessment of skills acquisition during laparoscopic surgery courses. Surg Innov. 2013;20:530-8

28. Sharma M, Macafee D, Horgan AF. Basic laparoscopic skills training using fresh frozen cadaver: a randomized controlled trial. Am J Surg. 2013;206:23-31.

29. Mann T, Gillinder L, Szold A. The use of virtual reality simulation to determine potential for endoscopic surgery skill acquisition. Minim Invasive Ther Allied Technol. 2014;23:190-7.

30. Berg DA, Milner RE, Fisher CA, Goldberg AJ, Dempsey DT, Grewal H A cost-effective approach to establishing a surgical skills laboratory. Surgery. 2007;142:712-21. 